\title{
DESPERATELY SEEKING A COMMUNICATIVE APPROACH: ENGLISH PRONUNCIATION IN A SAMPLE OF FRENCH AND POLISH SECONDARY SCHOOL TEXTBOOKS
}

\author{
ALICE HENDERSON \\ Université de Savoie \\ Alice.Henderson@univ-savoie.fr \\ ANNA JAROSZ \\ University of Łódź \\ aejarosz@wp.pl
}

\begin{abstract}
This paper compares the treatment of English pronunciation in school textbooks from France and Poland, in order to see what resources teachers have at their disposal. It is limited to textbooks used at the secondary level of each education system. Recent research has shown that European teachers do not find teaching English pronunciation easy and that many are unsatisfied with their training in relation to teaching pronunciation (Bradford \& Kenworthy 1991; Burgess and Spencer 2000; Henderson et al. 2012; Frost and Henderson, 2013; Iivonen, 2005). Textbooks are a widespread resource with the potential to alleviate a lack of extensive pedagogical training.

The first part of this paper analyses pronunciation exercises in a representative sample of textbooks from each country. Pronunciation exercises were classified based on the degree to which they mobilize communicative abilities, according to the five categories of a Communicative Framework for teaching pronunciation (Celce-Murcia et al., 2010, p45): Description \& analysis, Listening discrimination, Controlled practice, Guided practice, Communicative practice. The first category involves little risk-taking by the learner, usually focusses on form and allows little freedom. At the other end of the spectrum, communicative practice involves a focus on meaning and interaction, with the concomitant greater freedom to make mistakes. The exercises were then analysed to see which segmental and/or prosodic features they favoured and to what extent.
\end{abstract}

\section{Introduction}

In European education systems, a communicative approach is usually the dominant paradigm in foreign language textbooks and teaching materials. Attaining communicative competence (Hymes, 1972) is the overall goal, as is clear in CEF "cando" descriptors for Spoken Interaction and for Spoken Production, such as Level B2 Interaction: "I can interact with a degree of fluency and spontaneity that makes regular interaction with native speakers quite possible. I can take an active part in discussion in familiar contexts, accounting for and sustaining my views". Strategic competence 
(Canale and Swain, 1980) underlies this goal, with its focus on use more than on usage; success involves learners expressing themselves and understanding others in interaction.

It follows that, if interaction is both the means and the ultimate goal in a communicative approach (ibid.), then speaking should logically receive at least as much attention as reading, writing and listening. Concurrently, given what is now known about the importance of intelligible pronunciation in spoken interaction, one could also reasonably expect pronunciation to be a primary focus of school textbooks, teaching materials and classroom activities. Unfortunately, for a variety of reasons pronunciation teaching "does not always make for a comfortable fit with instructors who support communicative language teaching" (Foote et al., 2013, 1). Foote et al. (ibid.) summarize four reasons for this: a belief that explicitly teaching pronunciation has little or no effect - and might even be counter-productive; a perception that integrating pronunciation into all-skills classes is hard; the assumption that factors beyond a teacher's control (notably age of learning, native language and aptitude) have more impact on pronunciation learning than on other skills; the reality of mixed-levels groups despite streaming based on placement tests- which typically do not test pronunciation skills. It is understandable that European teachers, who often feel dissatisfaction with pre-service training concerning the teaching of pronunciation (Bradford and Kenworthy 1991; Burgess and Spencer 2000; Henderson et al. 2012; Frost and Henderson, 2013; Iivonen, 2005), would focus their efforts elsewhere. They might, for example, use a number of English pronunciation teaching materials available on the market as a supplementary and additional teaching aid, but the earlier study by Szpyra-Kozłowska (in Sobkowiak and Waniek-Klimczak, 2006, 216) shows that even though they "contain a wealth of interesting ideas how to teach English pronunciation" (ibid.) they are not perfect and they provide descriptions of phonetic articulation which are too "simplified". Moreover, taking into account the limited number of hours of English in a secondary school (where it is just another subject in an already busy school day) and the time pressure resulting from the school-leaving exams, it seems obvious that teachers will not reach for extra pronunciation tasks to add to coursework.

But textbooks could help solve the problem, as they have the potential to guide teachers in effective pronunciation teaching: "Because many ESL instructors have limited training and confidence in teaching pronunciation, it falls to general-skills textbooks to ensure that pronunciation is addressed in L2 classrooms." (Derwing et al., 2012, 25). Despite the rise of on-line resources ${ }^{1}$, printed textbooks are the prevalent tool to which teachers have access. And while they should not be confused with classroom reality, textbooks nonetheless constitute a useful window onto teaching practices; in Finland, for example, "the teacher's guides offer ready-made course schedules and lesson plans" (Tergujeff, 2010, 191). Furthermore, Bragger and Rice (2000) argue that textbooks are used "for curriculum design, for lesson planning, as a basis for assessment, and perhaps too often, to define their [instructors'] approach to teaching" (107). European school textbooks may or may not be designed for the local context by publishers but they tend to be all-inclusive general course books in which publishers take

\footnotetext{
${ }^{1}$ Publisher-controlled digital textbooks and resources (Bruillard, 2011; SOFRES 2010) are more and more common, but teachers can and do search the Web for exercises and/or "raw" content (which they then transform into teaching materials).
} 
into account the national curriculum; for example, in Poland British publishers regularly invite Polish authors to contribute their expertise to textbook series. Curricula, in turn, tend to be aligned with the Common European Framework of Reference for Languages (Council of Europe, 2001), which emphasizes a communicative approach to language teaching. To conclude, teachers would seem to need to address pronunciation if their learners are to meet CEFR criteria and textbooks could potentially reduce the gap left by inadequate pre-service training.

While the CEFR emphasizes the goal of spoken interaction, it is clear that for many learners and teachers pronunciation work to that end will be an uncomfortable experience. Spoken interaction involves bringing one's ideas into the public domain and this can be daunting for many speakers; voicing ideas in a foreign tongue involves even greater risk. One's pronunciation is "a powerful sociological force; it reveals our group affiliation and often how we see ourselves" (Celce-Murcia et al., 2010, 279); teachers might lack confidence in their own accent. Pronunciation work is therefore likely to be a more affective experience than, say, doing grammar exercises. For learners this could be especially true because, as exercises become more communicative, moving away from a focus on form and a limited potential for error, the level of freedom and risk concomitantly increases. Therefore, either textbooks need to provide a structured approach to pronunciation work or teacher training needs to sufficiently prepare teachers to fill-in the gaps and prioritise.

Any textbook analysis needs to address the issue of which types of pronunciation features are important for communication. A long-standing debate continues about the relative importance of segmental or prosodic features and research has started to generate useful evidence. One significant influence in recent decades comes from studies of English as a Lingua Franca (ELF) (e.g. Jenkins 2000; Seidlhofer 2001). Seidlhofer defines ELF as "any use of English among speakers of different first languages for whom English is the communicative medium of choice, and often the only option." $(2011,7)^{2}$. Based on the analysis of interactions between non-native speakers, Jenkins proposes a lingua franca core (LFC) syllabus with only two prosodic elements (tone units/word groups and nuclear stress). Other research shows that focussing on intonation and both nuclear and lexical stress affect intelligibility (Munro and Derwing, 2011; Field, 2005; Derwing et al. 1998). Yet more research shows that distinguishing between certain segments rather than others is also important. For example, the ship-sheep distinction should be preserved (e.g. Munro and Derwing, 2006). This is in concordance with Jenkins including vowel length (tense/lax) and consistency in vowel quality in the Lingua Franca Core; it is not problematical to pronounce <bat> as <bet> but it should always be pronounced that way. Catford's principle of relative functional load (RFL), which takes into account frequency of occurrence, is another useful criterion for prioritizing segmental features (1987). The RFL of a phonemic contrast is measured by determining how many pairs of words are differentiated by that contrast, e.g. ship-sheep, tin-thin. It might not be worth spending time on features with low RFL, e.g. dental

\footnotetext{
${ }^{2}$ Native speakers of English could be involved in ELF interactions but would be in the minority and would have to adapt to their listeners' needs in terms of intelligibility and ease of understanding.
} 
fricatives, even if learners have difficulty with them and/or the features do not exist in their mother tongue.

Therefore, our research questions are:

- Are textbooks providing exercises to guide teachers in a structured approach to teaching pronunciation?

- And if yes, does that structure lead towards progressively more communicative work?

- Do pronunciation exercises tend to deal with segmental features more or less than prosodic ones?

We hypothesize that textbooks are not providing structured, communicative materials in relation to pronunciation and that what pronunciation work there is tends to focus on segmental features. In an attempt to confirm or refute these hypotheses, we start by describing the national contexts in which teachers use certain textbooks, before explaining our methodology. Results are discussed in relation to contrastive analysis, common claims about learners' potential difficulties, the Lingua Franca Core, and relative functional load, to partially assess the appropriateness of features dealt with in textbooks.

\subsection{National Contexts}

The societal perceptions of English are notably different between France and Poland. In France the "Toubon Law" of 1994 and the influence of the Académie Française (whose objective is to protect the purity of the French language) reveal that English is seen as being in direct competition with French and as a threat to national identity. For example, the Toubon Law stipulates that the French language is a fundamental element of the "personality and heritage of France" and that it is "the language of teaching, of work, of exchanges and public services $»^{3}$. However, the official line is undergoing forced change, perhaps due to the influence of Internet (e.g. streaming), the best example being the decision taken in December 2012 by the French national TV channel to show an American series in English with subtitles every Monday evening. Conversely, in Poland learning English is seen as a necessity for a variety of reasons, including economic, and concomitant questions of status and purity do not seem to be at the fore. According to Spiewak and Golebiowska (in Swan and Smith, 2001, 162), since 1989 "the role of English, always a popular language, has dramatically increased. English is now considered an essential part of a good education, and is widely taught in and out of schools. Many employers organize in-service EFL courses."

The education systems in Poland and France are similar, with obligatory primary education being from age 6-10 (France also provides schooling from age 3-5), followed by secondary education. In France the system is divided into lower/collège (11/12 14/15 yrs) and upper/lycée levels (15+ yrs). Pupils in the language and literature stream (the "Bac L") should have obtained the CEFR level of B1/B2 at the end of the lower

\footnotetext{
${ }^{3}$ Law n ${ }^{\circ}$ 94-665, August 4, 1994.
} 
collège, rising to $\mathrm{C} 1 / \mathrm{C} 2$ level at the end of lycée; pupils in other streams are not expected to reach as high a level. Secondary education in Poland is also divided into two levels: lower/gimnazjum (12/13 - 14/15) and upper/liceum (15/16 - 18/19). At the end of the upper secondary school students have a choice of two levels of the English schoolleaving written exam: B1 or B2+ depending on their linguistic competence gained throughout their education.

In both countries the official texts and rules governing textbook use are very similar. A wide variety of textbooks exists as well as a plethora of accompanying resources (workbook, on-line workbook, CDs, websites). Textbooks tend to change every 2-4 years, either due to reforms in the system or, in Poland due to changes in school-leaving exams. If publishers hope to sell textbooks, they must conform to official national curricula; anecdotal evidence reveals that using approved textbooks gives teachers the feeling that they are therefore following the guidelines. In France, no obligatory titles are imposed by the Ministry of Education. However, a list of suggested titles is published annually, as in Poland, where it can be quite long: 33 textbooks for primary elementary level, 23 for upper primary level, 40 at gimnazjum level and 32 at liceum level.

In contrast with Poland, in French schools teachers often decide to not use a textbook, especially at lycée level. One teacher went so far as to say "We don't use any textbooks any more (what's the point with the internet and all this constantly updated information, easily downloadable videos etc.)", whereas another at collège level wrote "as far as phonetics is concerned, I tend to use my own documents, as there is not much in the books." (E-mail, October 2013).

\section{Methodology}

\subsection{Textbooks}

This study focusses on secondary school textbooks. In France this includes both collège and lycée levels (learners aged 11-18). In Poland this covers both lower and upper secondary (gimnazjum and liceum) (learners aged 12-18/19). Twenty teachers in each country were asked (via e-mail and in person) which books they use and, from among those titles, the most popular or frequently mentioned were selected; the final list includes books from different publishers. Accompanying resources such as CDs or Web sites $^{4}$ were excluded not only because teachers use them differently, but also because it could be argued that their use "will be reflected in the number and range of pronunciation activities in the textbooks themselves." (Derwing et al., 2012, 22).

\footnotetext{
${ }^{4}$ For example, the French publisher Nathan has a Web site to accompany their textbook series New Bridges : http://www.nathan.fr/webapps/cpg2-5/default.asp?idcpg=1389\&accueil=1. This provides videos, sound files, an on-line textbook, interactive exercises, PDF documents, etc. and seems to be common practice amongst French publishers.
} 


\begin{tabular}{|c|c|c|c|}
\hline Level & Name of book & Publisher & School Year \\
\hline \multirow{2}{*}{$\begin{array}{l}\text { Lycée } \\
\left(\begin{array}{l}\text { (15+yrs }: 2^{\text {nde, }, \text { ière and }} \\
\text { Terminale })\end{array}\right.\end{array}$} & Meeting Point 2011* & Hatier & $1^{\text {ère }}$ \\
\hline & New Bridges 2010 & Nathan & $\begin{array}{l}2,1, \\
\text { Terminale }\end{array}$ \\
\hline $\begin{array}{l}\text { Collège } \\
\left(11-14 \text { yrs }: 6^{\text {ème-3ème }}\right)\end{array}$ & $\begin{array}{l}\text { Enjoy English (2006- } \\
2008)^{*}\end{array}$ & Didier & $\begin{array}{l}6^{\text {ème }}, 4^{\text {ème }} \\
3^{\text {ème }}\end{array}$ \\
\hline
\end{tabular}

Table 1: French secondary school textbooks analysed (*Workbook also analysed)

Focussing on the most popular French books in each school level, 7 textbooks and 4 workbooks were examined, from 3 different publishers (Table 1). As for the Polish textbooks, each textbook is accompanied by a separate workbook, but pronunciation tasks are usually included in the textbooks; a recent trend seems to be to include a pronunciation section (about three pages altogether) at the end of the workbook. Therefore, 11 textbooks and 11 workbooks from 3 publishers were analysed, as shown in Table 2 below.

\begin{tabular}{|l|l|l|}
\hline Level & Name of book & Publisher \\
\hline \multirow{4}{*}{$\begin{array}{l}\text { Upper } \\
\text { Secondary }\end{array}$} & Matura Prime Time Upper-Intermediate & $\begin{array}{l}\text { Express } \\
\text { Publishing 2011 }\end{array}$ \\
\cline { 2 - 3 } & New Matura Solutions Upper-Intermediate & Oxford 2011 \\
\cline { 2 - 3 } & New Matura Solutions Intermediate & Oxford 2011 \\
\cline { 2 - 3 } & New Matura Solutions Pre-Intermediate & Oxford 2011 \\
\hline \multirow{4}{*}{$\begin{array}{l}\text { Seconer } \\
\text { Upstream Intermediate }\end{array}$} & $\begin{array}{l}\text { Express } \\
\text { Publishing 2010 }\end{array}$ \\
\cline { 2 - 3 } & $\begin{array}{l}\text { Exam Challenges 3 } \\
\text { Publishing 2009 }\end{array}$ \\
\cline { 2 - 3 } & $\begin{array}{l}\text { English Plus 1,2,3,4 (Workbooks with the } \\
\text { pronunciation section at the back) }\end{array}$ & $\begin{array}{l}\text { Pearson } \\
\text { Longman 2009 }\end{array}$ \\
\cline { 2 - 3 } & Oxford 2011 \\
\hline
\end{tabular}

Table 2: Polish textbooks analysed

For the first 7 titles the pronunciation work is included in the textbook, whereas in the English Plus textbook pronunciation work is non-existent; all pronunciation work has been relegated to the special pronunciation section at the end of the workbook. 


\subsection{Categorizing Data}

Three questions probe aspects of the exercises relevant to this study:

- To what extent do they encourage communicative interaction?

- Do they treat segmental or prosodic features?

- Which features in particular do they cover?

In response to the first question, the Communicative Framework of Celce-Murcia et al. $(2010,45)$ was used to categorize exercises. Table 3 presents the Framework's five categories and their description in the middle and right-hand columns; a left-hand column has been added, to present a continuum of levels of risk and freedom, as well as of degrees of focus on form.

\begin{tabular}{|c|c|c|}
\hline $\begin{array}{l}\text { Level of risk \& } \\
\text { freedom, degree } \\
\text { of focus on form }\end{array}$ & $\begin{array}{l}\text { Exercise } \\
\text { categories }\end{array}$ & Description of exercises \\
\hline \multirow{3}{*}{$\begin{array}{l}\text { Low risk } \\
\text { Little freedom } \\
\text { Focus on form }\end{array}$} & $\begin{array}{l}\text { Description \& } \\
\text { Analysis }\end{array}$ & $\begin{array}{l}\text { Oral \& written descriptions of how the } \\
\text { feature is produced \& when it occurs within } \\
\text { spoken discourse }\end{array}$ \\
\hline & $\begin{array}{l}\text { Listening } \\
\text { discrimination }\end{array}$ & $\begin{array}{l}\text { Focussed listening practice on learners' } \\
\text { ability to correctly discriminate the feature }\end{array}$ \\
\hline & $\begin{array}{l}\text { Controlled } \\
\text { practice }\end{array}$ & $\begin{array}{l}\text { Focus on highlighted feature in order to } \\
\text { raise learner consciousness, e.g. oral } \\
\text { reading of minimal pair sentences, short } \\
\text { dialogues, etc. }\end{array}$ \\
\hline \multirow{2}{*}{$\begin{array}{l}\text { High risk } \\
\text { Great freedom } \\
\text { Focus on } \\
\text { meaning }\end{array}$} & Guided practice & $\begin{array}{l}\text { Learner monitors for the specified features, } \\
\text { e.g. structured communication exercises, } \\
\text { information-gaps, cued dialogues, etc. }\end{array}$ \\
\hline & $\begin{array}{l}\text { Communicative } \\
\text { practice }\end{array}$ & $\begin{array}{l}\text { Learner attends to both form \& content, less } \\
\text { structured, fluency-building, e.g. role play, } \\
\text { problem solving }\end{array}$ \\
\hline
\end{tabular}

Table 3: Exercise categories (adapted from Celce-Murcia et al., 2010, 45)

While the implied goal is for exercises to provide communicative practice, exercises in the other categories also provide valuable practice in the progression towards greater learner autonomy and focus on meaning or, to refer to Canale and Swain (1980) towards use rather than usage.

Table 4 provides examples of typical textbook instructions or criteria used in this study to classify exercises according to the above categories. 


\begin{tabular}{|l|l|}
\hline $\begin{array}{l}\text { Description and } \\
\text { Analysis }\end{array}$ & $\begin{array}{l}\text { Rules; classifying; reflecting, noticing } \\
\text { ('think about'/'what do examples show?') } \\
\text { (to illustrate how/when a feature occurs) }\end{array}$ \\
\hline $\begin{array}{l}\text { Listening } \\
\text { discrimination }\end{array}$ & $\begin{array}{l}\text { Explicit comparing: 'Listen \& check/note' } \\
\text { (to correctly discriminate a feature) }\end{array}$ \\
\hline Controlled practice & $\begin{array}{l}\text { Oral reading aloud: 'Listen \& repeat', 'Now you try' } \\
\text { (to raise consciousness of a feature) }\end{array}$ \\
\hline Guided practice & $\begin{array}{l}\text { At least } 1 \text { open-ended model is provided, visually or orally (to } \\
\text { allow monitoring of a feature's form) }\end{array}$ \\
\hline $\begin{array}{l}\text { Communicative } \\
\text { practice }\end{array}$ & $\begin{array}{l}\text { *Excluding speaking exercises lacking explicit reference/clear } \\
\text { link to pronunciation work (to allow monitoring of form \& } \\
\text { content) }\end{array}$ \\
\hline
\end{tabular}

Table 4: Typical instructions for each exercise category

In the Description \& Analysis category we included writing exercises which required noticing or thinking about a pronunciation feature, even though Celce-Murcia et al. do not mention them. A distinction was then made between "Listen and Check/Note" and "Listen and repeat/Now you try", the latter being seen as more active. Guided Practice exercises often accompanied a drawing with an open-ended structural model provided; the following example from a collège level textbook follows on from a Controlled Practice exercise on compound nouns (e.g. sunscreen, fishing rods, car tyres):

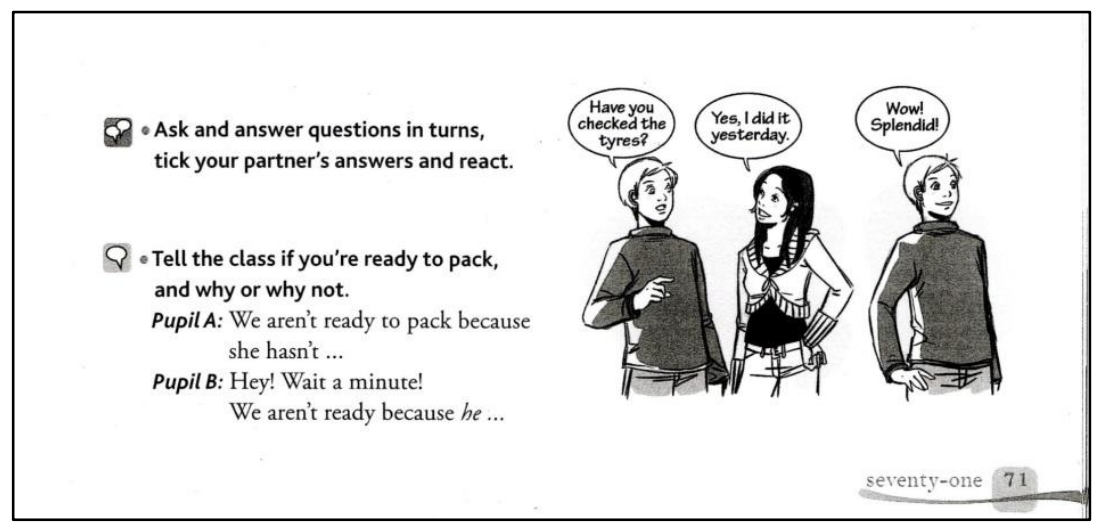

Figure 1: Example of a Guided Practice exercise, from Enjoy English (4ème) (Martin-Cocher et al., 2012, 71)

Finally, numerous speaking and listening exercises were excluded from the category Communicative Practice unless they explicitly referred to a pronunciation feature. Moreover, numerous exercises actually involved two categories of communicative level, for example one separate instruction would encourage the learner to pay attention to a 
feature ("put the words with a similar sound in the same column") followed later by a separate instruction "now practice with a partner". These count as two separate exercises, the former as Description \& Analysis and the latter as Controlled Practice. The pair "Listen \& Repeat" when written together was counted as one instruction and categorised as Controlled Practice.

In order to determine whether each exercise focussed on segmental or prosodic features, the instructions for individual exercises were analysed. Classifying features can be interesting in its own right, especially as textbooks may not concur with basic linguistic theory. The most striking case is the -ED ending, which is frequently worked on in textbooks as a segmental, along with consonants. However, it should be seen as a prosodic feature; a frequent learner error involves syllabification of -ED and final -ES as a coda. Similarly, the "LL or "dark L" of contracted forms is presented as a segmental in a Polish textbook, where the exercise contrasts $I$ go and I'll go - without mentioning $I$ will go. In the case of I will go, arguably a more usual contrast with I'll go, there would be a change in sentence stress or focus and for this reason 'LL is categorized as prosodic.

The final step simply involved listing the features which were covered and the number of occurrences. This data revealed which features tend to be addressed most and least frequently.

\section{Results and Discussion}

The data will be presented from three perspectives: the communicative degree of exercises, the segmental or prosodic nature of each exercise's main pronunciation focus, and which particular feature. In order to assess the value of including features in textbooks, results will be compared to several references: the contrastive analyses of Swan and Smith's 2001 Learner English and of Rogerson-Revell's more recent English Phonology and Pronunciation Teaching (2011), Jenkins' 2000 Lingua Franca Core, and Catford's 1987 principle of relative functional load.

\subsection{Exercise Types: How communicative?}

The degree to which each exercise promotes communicative interaction was established by categorizing exercises according to Celce-Murcia's framework for the teaching of pronunciation $(2010,45)$. Table 5 displays the percentage of occurrences of exercises for each category of this framework: Description \& Analysis, Listening Discrimination, Controlled Practice, Guided Practice, and Communicative Practice: 


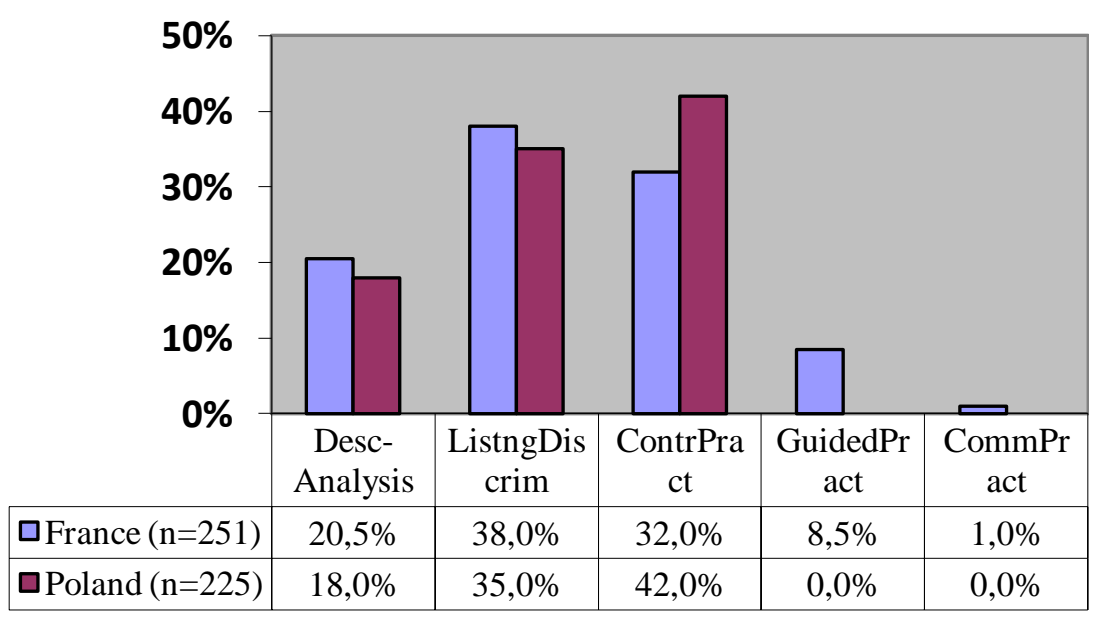

Table 5: Percentage of occurrences of exercises per category (*Only occurred in upper secondary school textbooks)

The predominant category types for both sets of textbooks are Listening Discrimination and Controlled Practice. The percentages in the Desc-Analysis category $(20.5 \%$ FR//18\% PL) are perhaps higher than they should be, because the category includes written exercises which required thinking/noticing/inductive reasoning. At the other end of the scale, CommPract is non-existent in Poland and almost non-existent in France. Excluded from this category were speaking exercises which did not follow directly from explicit pronunciation work or which did not make explicit reference to pronunciation features in instructions. The results confirm those of Tergujeff's (2010) data-driven study, wherein Finnish textbook exercises came primarily from the Desc-Analysis and Controlled Practice categories. Moreover, in their study of general skills ESL textbooks Derwing et al. found that listen \& repeat was "the task most consistently used across all the series analysed" $(2012,35)$.

\subsection{Segmentals or prosodic features?}

The segmental or prosodic nature of pronunciation focus in textbook exercises is presented in Table 6 as percentages of the total number of exercises: 


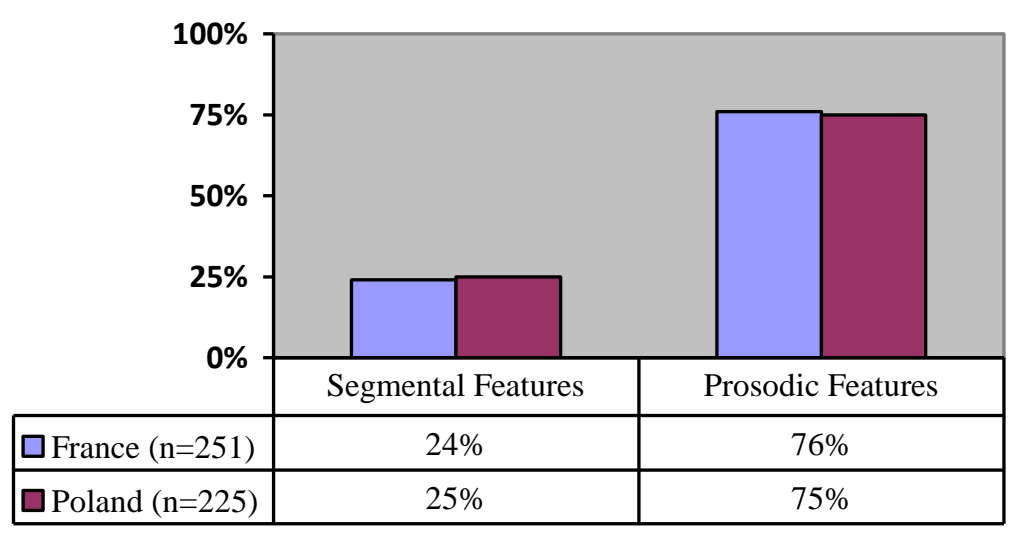

Table 6: Percentage of occurrences of segmental and prosodic exercises

Table 6 shows clearly how prosody dominates in both the French and Polish textbooks. However, when the Polish $25 \%$ for segmentals is further broken down, segmentals are barely dominant at lower secondary level $(53.5 \%)$ but are nearly non-existent at upper secondary level $(7 \%)^{5}$. This "heavier weighting toward suprasegmentals" was also found in Derwing et al. (2012, 33). Conversely, in her study of Finnish EFL textbooks, Tergujeff found that prosodic elements were totally absent, except for a brief mention of Linking $-<r>$ and intonation in one-word questions (2010).

\subsection{Which segmental features?}

Table 7 lists the segmental features dealt with in textbooks, revealing overall variety, and further similarities and differences between French and Polish textbooks. A key word (e.g. EAT, SNOW) is provided when no IPA symbols were used in the textbook; inversely, if a symbol appears in the table, it appeared that way in the textbooks. The entry "stressed vowel" refers to instructions like "Group together words that rhyme"; this instruction was used several times for various vowels. It is worth remembering that 22 Polish books were analysed; therefore, despite the similar numbers of exercises in Table $7(n=51, n=57)$, the 11 French textbooks provide proportionately almost twice as many exercises on pronunciation. In the Polish data, it is notable that the exercises come solely from lower secondary textbooks, except for one exercise on used/used to.

\footnotetext{
${ }^{5}$ Furthermore, unpublished preliminary data from primary school level shows that segmentals dominate $93 \%$ of textbook exercises in a French sample and $70 \%$ in a Polish sample.
} 


\begin{tabular}{|c|c|c|c|c|}
\hline & \multicolumn{4}{|c|}{ Segmental features ( ${ }^{\circ}$ of occurrences) } \\
\hline & & France TOTAL $n=51$ & & Poland TOTAL $n=57$ \\
\hline \multirow{9}{*}{$\begin{array}{l}\text { Most } \\
\text { common }\end{array}$} & \multirow{6}{*}{$\mathrm{n}=5$} & \multirow{6}{*}{ SNOW, EAT } & $\mathrm{n}=10$ & /i: I/ \\
\hline & & & $\mathrm{n}=9$ & schwa \\
\hline & & & $\mathrm{n}=6$ & /eI aI əU av/ \\
\hline & & & $\mathrm{n}=6$ & /eI aI əU Iə еə/ \\
\hline & & & $\mathrm{n}=6$ & $/ \theta$ ठ f v/ \\
\hline & & & $\mathrm{n}=5$ & silent letters \\
\hline & $\mathrm{n}=4$ & $\begin{array}{l}\text { / } \theta \text { ə s z/, } \\
\text { Diphthongs in general }\end{array}$ & $n=4$ & -ing / $\mathrm{n} /$ \\
\hline & $\mathrm{n}=3$ & $\begin{array}{l}<\mathrm{H}>, \text { CAT/CAR, Explicitly } \\
/ \partial /\end{array}$ & $n=3$ & $\mid æ \Lambda$ \\
\hline & $\mathrm{n}=2$ & $\begin{array}{l}/ \mathrm{t} \int \mathrm{S} /, \mathrm{THERE}, \mathrm{IT}, \mathrm{BED}, \\
\mathrm{COST} / \mathrm{BLOOD}, \text { Vowels in } \\
\text { general }\end{array}$ & $n=2$ & $\begin{array}{l}\text { Spelling/pronunciation: }\langle\mathrm{OU}\rangle \text {, } \\
\langle\mathrm{G}\rangle,\langle\mathrm{A}\rangle\end{array}$ \\
\hline $\begin{array}{l}\quad V \\
\text { Least } \\
\text { common }\end{array}$ & $\mathrm{n}=1$ & $\begin{array}{l}\langle\mathrm{TH}\rangle \&\langle\mathrm{CH}\rangle, " \mathrm{~T} \text { in the } \\
\text { middle", FEAR, DOWN, } \\
\text { BOY, DAY, Spelling/pron: } \\
\langle\mathrm{OW}\rangle-<\mathrm{O}\rangle-<\mathrm{I}\rangle \text {, } \\
\text { CUT/COT, Stressed vowel }\end{array}$ & $\mathrm{n}=1$ & $\begin{array}{l}/ \theta \text { ə t d/, Spelling/pronunciation } \\
\text { used/used to }\end{array}$ \\
\hline
\end{tabular}

Table 7: Occurrences of segmental exercises ( $n=$ number of occurrences)

The vowel of EAT and diphthongs, esp. that of SNOW, are the most commonly dealt with segmental features in both countries; this seems appropriate given that the minimal pairs/i: I/ and / ว: $ə \mho /$ have a high relative functional load, $95 \%$ and $88 \%$ respectively (Catford, 1987). Explicit reference to schwa - and not just "weak forms" or unstressed syllables- was found in both sets of textbooks, as was explicit work on letter-to-sound correspondence and dental fricatives. The latter have a low functional load (ibid.) and yet TH-variation can be stigmatized or at least sociolinguistically salient (e.g. Labov 1966, Hickey 2000.); however, in these books dental fricatives might be given more attention than they should receive simply because they are absent from the consonant inventory of both Polish and French.

According to Spiewak and Golebiowska (in Swan and Smith, 2001), major problems for Polish learners include predicting sounds from spelling, accurately producing consonants (especially the dental fricatives, the voiced velar nasal and inappropriate final 
devoicing), and vowels represent "an area of great difficulty and potential confusion. [...] open vowels are the single most difficult area" (164). Diphthongs do not exist in Polish and the second element of closing diphthongs tends to be pronounced with a / j/ or /w/ approximant. Moreover, maintaining the length of diphthongs is a priority in the LFC. For all these reasons, it is appropriate that they be covered in the textbooks.

Rogerson-Revell $(2011,286)$ mentions difficulty distinguishing between tense and lax vowels, specifically citing the /i: I/ minimal pair, which is the most frequently occurring feature in the exercises. This is in concordance with vowel length (tense/lax) being included the LFC. Rogerson-Revell also mentions /æ e $\wedge /$ as being difficult, of which the pair /æ $\Lambda$ / has a non-negligible relative functional load (65\%) (Catford, 1987). It is interesting that schwa is the second most frequently occurring segmental feature in the Polish textbooks' exercises and yet it is not a priority in the LFC, either as an explicitly addressed segmental or related to a prosodic feature. Conversely, the Polish textbooks analysed make no mention of either the English affricates or $/ \int 3 /$, though they are mentioned by Spiewak and Golebiowska (in Swan and Smith, 2001) as potentially troublesome.

French learners share certain difficulties with Polish learners, so one would expect some overlap in the segmental features addressed in their textbooks. There is no distinction between tense and lax vowels in French and the exercises provide partial cover of this. Presumably the /æa:/ distinction is covered not for its relative functional load, which is only 38\% (Catford, 1987), but rather because it is a common salient feature distinguishing between American and British varieties (e.g. grass, bath, example, advantage). Schwa is explicitly referred to, and not merely mentioned in exercises on "weak forms" or "unstressed syllables". Aspiration of initial voiceless plosives is not mentioned but is obligatory in the LFC (when in initial position in a stressed syllable) whereas the French textbooks give diphthongs and dental fricatives top priority. In Swan and Smith (2001) the latter are described as problematical in production for French learners; for Poles "interdentals are a nightmare" according to Spiewak and Golebiowska (ibid.).The dental fricatives are given relatively more attention in the French textbooks, despite being unnecessary in the LFC (Jenkins, 2000) and having low functional load (Catford, 1987).

Exercises dealing explicitly with letter-to-sound mismatches should arguably focus on the more predictable aspects. For example, Carney (1994) found that in 94\% of occurrences of $\langle\mathrm{oa}\rangle$, the pronunciation is $/ \partial v /$. It is therefore unclear why such exercises address less productive relations, such as $\langle\mathrm{ow}\rangle(53 \%)$ and $<0\rangle(76 \%)$.

\subsection{Which prosodic features?}

Table 8 lists the prosodic features dealt with in textbooks, showing that exercises treating intonation dominated while other preferences differed, most notably for -ED, -S/-ES endings. 


\begin{tabular}{|c|c|c|}
\hline & \multicolumn{2}{|c|}{ Prosodic features ( ${ }^{\circ}$ of occurrences) } \\
\hline & France TOTAL $n=200$ & Poland TOTAL $n=168$ \\
\hline \multirow{2}{*}{$\begin{array}{l}\text { Most } \\
\text { common }\end{array}$} & $\begin{array}{l}\text { Intonation }(n=40) \\
\text { Sentence stress }(n=35)\end{array}$ & $\begin{array}{l}\text { Intonation }(n=52) \\
\text { Word Stress }(n=26)\end{array}$ \\
\hline & Word Stress $(\mathrm{n}=27)$ & $\begin{array}{l}\text { Past tense ED }(n=22) \\
\text { Weak Forms }(n=18) \\
\text { 3rd pers. sing. }(n=16)\end{array}$ \\
\hline & Focus $(n=25)$ & \multirow{2}{*}{ Sentence Stress $(n=12)$} \\
\hline & \multirow{2}{*}{$\begin{array}{l}\text { Weak forms }(n=20) \\
\text { Rhythm }(n=10) \\
\text { Pausing/Breath groups }(n=9)\end{array}$} & \\
\hline & & Contractions $(n=7)$ \\
\hline & $\begin{array}{l}\text { Endings }(S, E S, E D)(n=5) \\
\text { Speed }(n=5) \\
\text { Linking in general }(n=5)\end{array}$ & $\begin{array}{l}\text { Linking }(n=6) \\
\text { Syllables }(n=4) \\
\text { «dark } L »(n=2)\end{array}$ \\
\hline $\begin{array}{l}\text { Least } \\
\text { common }\end{array}$ & $\begin{array}{l}\text { Linking } C+V \text {, CAN'T (hearing } \\
\text { negatives) }(n=3) \\
\text { Linking } R(n=2) \\
\text { Article } a / a n(n=1)\end{array}$ & $\begin{array}{l}\text { Focus }(n=2) \\
\text { Hearing negatives }(n=1)\end{array}$ \\
\hline
\end{tabular}

Table 8: Occurrences of prosodic exercises

Intonation and word/lexical stress are top priorities in both sets of books whereas linking is not. Derwing et al.'s (2012) study of general ESL textbooks revealed the same hierarchy of prosodic foci as in the French textbooks: Intonation, Sentence Stress and Word stress. The most puzzling difference between the two sets of European school textbooks is the frequency of exercises highlighting focus: 25 exercises deal with focus in the French textbooks but only 2 were found in the Polish textbooks. Focus, or nuclear stress, and word groups are the only two prosodic features included in Jenkins' LFC. Without explicitly mentioning focus, Swan and Smith's Learner English mentions that both French and Polish learners have trouble with the predominantly stress-timed rhythm of English, so one could extrapolate and assume that focus would also be difficult (2001). Moreover, according to Gray, (2013) "The importance of teaching nuclear placement strategies to non-native learners is widely accepted". Its low priority in the Polish textbooks is therefore questionable.

Conversely, the Polish books attend extensively to -ED endings and $3^{\text {rd }}$ person singular endings; this is understandable, given that the English spelling system isn't phonemic (whereas Polish is). However, French learners also struggle with English letter-to-sound correspondences so it is hard to explain the low frequency of exercises on this feature. 
In terms of stress, the French books pay proportionately more attention to both lexical/word stress and sentence stress. Both sets of books lend intermediate status to Weak Forms, with the French ones including exercises explicitly on Rhythm. Exercises on speed are totally absent from the Polish books. Interestingly enough, the Polish books included 4 exercises on counting syllables. Two exercise-features (CAN'T or Hearing negatives and Article a/an) were not re-categorized (as Focus or Linking, for example) in order to show how textbooks present them. They are the least common features covered. It is worth remembering that 22 Polish books were analysed; therefore, despite the similar overall numbers of exercises in Table $8(n=200, n=168)$, the 11 French textbooks provide proportionately more than twice as many exercises on prosodic features.

\section{Conclusion}

This study set out to compare how English pronunciation was treated in a sample of secondary school textbooks in France and Poland, with the hope of finding a variety of exercises leading toward communicative language practice. Our first hypothesis has, unfortunately, been confirmed; the secondary school textbooks sampled do not provide much communicative material in relation to pronunciation. However, our second hypothesis is refuted; their pronunciation exercises do not tend to focus on segmental features.

It was suggested, on the basis of preliminary data, that segmental features are the focus of primary level education and further research would be necessary to confirm this. This groundwork could also be extended in other directions. It would doubtless be interesting to compare books intended for private sector use and those for public sector use, as publishers produce different books for the two. The Headway series by Oxford University Press, for example, is quite popular in the private sector but does not seem to be officially used in the public sector. Secondly, correlations between the exercise types and specific features could prove informative; for example, segmentals might tend to be dealt with more frequently in Listening Discrimination rather than Guided Practice.

Overall, the French textbooks in the current study cover pronunciation much more frequently than the Polish textbooks. More particularly, the results show that the predominant prosodic features are intonation and word/lexical stress but that the French textbooks attend to focus much more extensively than the Polish ones. On the other hand, the Polish textbooks treat $-\mathrm{ED}$ endings and $3^{\text {rd }}$ person singular endings much more than the French ones. Exercises devoted to segmental features are more varied, with the tense/lax distinction, diphthongs and dental fricatives being the most frequent. The continued presence of work on dental fricatives is perhaps due to a tradition of contrastive analysis or error analysis in prioritizing features in syllabi, although it was suggested that sociolinguistic issues might also influence choices. In any case, the exercises in both sets of textbooks failed spectacularly to provide exercises from the communicative end of Celce-Murcia's framework, as the predominant types of exercises were: Description \& Analysis, Listening Discrimination and Controlled Practice.

The onus is therefore on (well-trained and/or talented) teachers to extend such exercises into communicative pronunciation work, as part of a communicative approach where interaction is both the means to success and the hallmark of it. This has its own 
dangers, in that many teachers tend to feel time-starved and ill-equipped to design and deliver such work. It could be said that for the desperately seeking teacher, the search thus continues.

\section{References}

Bradford, B. and J. Kenworthy. 1991. Phonology on teacher training courses. Speak Out! 9: 12-15.

Bragger, J. and D. Rice. 2000. Foreign language materials: Yesterday, today and tomorrow. In R. Terry (ed) Agents of Change in a Changing Age. Lincolnwood, IL: National Textbook Company: 107-140.

Bruillard, E. 2011. Current textbook research in France: An overview. Proceedings of the international textbook symposium, ITS 2011. April 28, 2011, Seoul, Korea: 120133.

Burgess, J. and S. Spencer. 2000. Phonology and pronunciation in integrated language teaching and teacher education. System 28/2: 191-215. DOI: 10.1016/S0346251X(00)00007-5

Canale, M. and M. Swain. 1980. Theoretical bases of communicative approaches to second language teaching and testing. Applied Linguistics 1, 1-47.

DOI: 10.1093/applin/I.1.1

Carney, E. 1994. Survey of English spelling. London: Routledge.

Catford, J.C. 1987. Phonetics and the teaching of pronunciation. In J. Morley (ed) Current Perspectives on Pronunciation: Practices Anchored in Theory. Washington, DC: TESOL: $87-100$.

Celce-Murcia, M. et al. 2010. Teaching Pronunciation: A Coursebook and Reference Guide, $2^{\text {nd }}$ edition. Cambridge: Cambridge University Press.

Council of Europe. 2011. Common European Framework of Reference for Learning, Teaching, Assessment. Strasbourg: Language Policy Unit, Council of Europe. Available at: http://www.coe.int/t/dg4/linguistic/Source/Framework_en.pdf.

Derwing, T., Diepenbroek, L., and J. Foote. 2012. How well do general-skills ESL textbooks address pronunciation. TESL Canada Journal 30/1: 22-44.

Derwing, T., Munro, M. and G. Wiebe. 1998. Evidence in favour of a broad framework for pronunciation instruction. Language Learning 8/2: 217-235.

DOI: $10.1111 / 0023-8333.00047$

Field, J. 2005. Intelligibility and the listener: the role of lexical stress. TESOL Quarterly 39/3: 399-423. DOI: 10.2307/3588487

Foote, J. A., Trofimovich, P., Collins, L., and F.S. Urzúa. 2013. Pronunciation teaching practices in communicative second language classes. The Language Learning Journal: 1-16. DOI: 10.1080/09571736.2013.784345

Frost, D. and A. Henderson. 2013. Les résultats du sondage EPTiES (English Pronunciation Teaching in Europe Survey): Un aperçu des pratiques de l'enseignement de la prononciation dans plusieurs pays européens vu par les enseignants. Les Cahiers de l'APLIUT: Les langues de spécialité en Europe 32/1: 92-113. DOI: 10.4000/apliut.3586 
Gray, M. 2013. Training French-speaking learners to interpret accentually-signalled focus in English declarative sentences. Presentation at English Pronunciation: Issues and Practices (EPIP3): Proceedings of the Third International Conference. May 8-10, 2013, University of Murcia, Spain.,

Henderson, A., Frost, D. et al. 2012. The English Pronunciation Teaching in Europe Survey (EPTiES): Selected results. In Waniek-Klimczak, E., (ed.), Research in Language 10 v1: 5-27. DOI: 10.2478/v10015-011-0047-4

Hickey, R. 2000. Salience, stigma and standard. In L. Wright (ed) The Development of Standard English 1300-1800. Theories, Descriptions, Conflicts. London: Cambridge University Press: 57-72.

Hymes, D. 1972. On communicative competence. In J. Pride. and J. Homes (eds) Sociolinguistics: Selected Readings. Harmondsworth, England: Penguin: 269-293.

Iivonen, A. 2005. Fonetiikan merkitys kielenomaksumisessa ja - opetukessa. In Iivonen, A., Aulanko, R. and M. Vainio (eds) Monikäyttöinen Fonetiikka. $3^{\text {rd }}$ edition. Helsinki: University of Helsinki.

Jenkins, J. 2000. The Phonology of English as a Lingua Franca. Oxford: Oxford University Press.

Labov, W. 1966. The Social Stratification of English in New York City. Washington, D.C.: Center for Applied Linguistics.

Martin-Cocher, O. et al. 2012. Enjoy English (4 $\left.{ }^{\text {ème }}\right)$. Didier: Paris.

Munro, M. and T. Derwing. 2006. The functional load principle in ESL pronunciation instruction: An exploratory study. System 34: 520-531.

DOI: 10.1016/j.system.2006.09.004

Munro, M. and T. Derwing. 2011. The foundations of accent and intelligibility in pronunciation research. Language Teaching 44/3: 316-327.

DOI: $10.1017 / \mathrm{S} 0261444811000103$

Rogerson-Revell, P. 2011. English Phonology and Pronunciation Teaching, London: Continuum.

Seidlhofer, B. 2011. Understanding English as a Lingua Franca. Oxford: Oxford University Press.

Seidlhofer, B. 2001. Pronunciation. In R. Carter and D. Nunan (eds.) The Cambridge Guide to Teaching English to Speakers of Other Languages. Cambridge: Cambridge University Press: 56-65.

SOFRES 2010. Textbooks 2010: Paper and digital uses in lower secondary schools, (TNS Sofres/Savoir Livre survey). Available at http://www.sne.fr/img/file/pdf/SNE/Groupes/SOFRES-Digitools-Eng.ppt.

Spiewak, G. and L. Golebiowska. 2001. Polish speakers. In M. Swan and B. Smith (eds) Learner English: A Teacher's Guide to Interference and Other Problems, $2^{\text {nd }}$ edition. Cambridge: Cambridge University Press: 162-178.

Swan, M. and B. Smith 2001. Learner English: A Teacher's Guide to Interference and Other Problems, $2^{\text {nd }}$ edition. Cambridge: Cambridge University Press.

Szpyra-Kozłowska, J. 2006. Phonetic instructions in English pronunciation teaching materials - how useful are they? In W. Sobkowiak and E. Waniek-Klimczak (eds.) Dydaktyka Fonetyki Języka Obcego w Polsce. Referaty z szóstej Konferencji Naukowej w Mikorzynie. May 8-10 2006, Konin, Państwowa Wyższa Szkoła Zawodowa w Koninie: 216-230. 
Tergujeff, E. 2010. Pronunciation teaching materials in Finnish EFL textbooks. In A. Henderson (ed) English Pronunciation: Issues and Practices (EPIP): Proceedings of the First International Conference. June 3-5 2009, Université de Savoie, Chambéry, France. Université de Savoie, Laboratoire LLS: 189-205. DOI: 10.4304/jltr.3.4.599607 